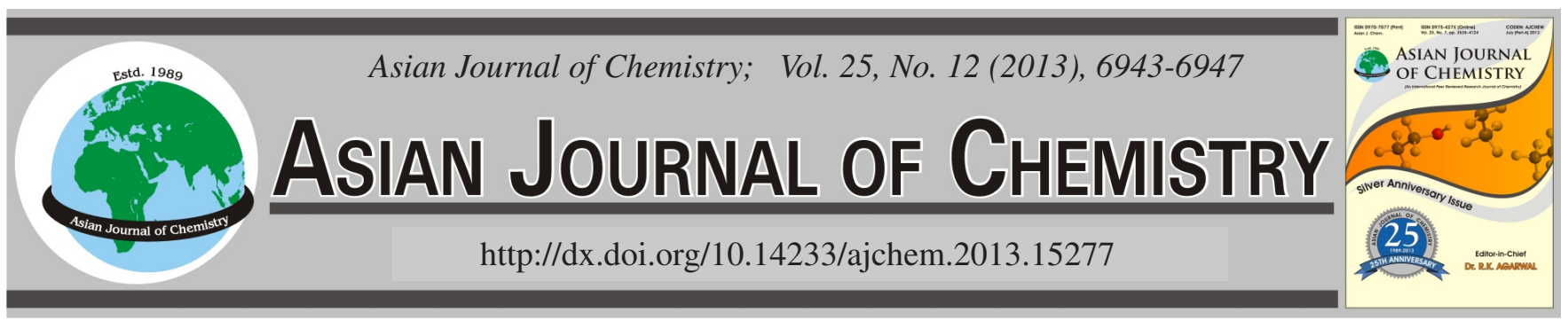

\title{
Novel Complex Fiber Biofilm Carrier in an Anaerobic/Anoxic/Oxic Reactor for Sewage Mixture Treatment
}

\author{
Dongkai Zhou ${ }^{1,2}$, Reti Hai ${ }^{1, *}$ and WenXing WANG ${ }^{1}$
}

${ }^{1}$ Department of Environmental Engineering, College of Chemical Engineering, Beijing University of Chemical Technology, Beijing 100029 , P.R. China

${ }^{2}$ Department of Environmental and Biological Engineering, Liaoning Shihua University, Fushun 113001, P.R. China

*Corresponding author: Tel/Fax: +86 10 64413170; E-mail: zhoudongk@126.com; hjzhx@buct.edu.cn

(Received: 4 February 2013;

Accepted: 7 June 2013)

AJC-13606

\begin{abstract}
A novel complex fiber filler was designed, which composed of an ultra-fine polypropylene fiber outer-coat and a polyacrylonitrile-based activated carbon fiber felt inner-core. And then the complex fiber filler was used as biofilm carrier in an anaerobic/anoxic/oxic $\left(\mathrm{A}^{2} / \mathrm{O}\right)$ process for sewage mixture treatment to remove organic carbon, nitrogen and phosphorus. During the continuous tests in three Periods, the $\mathrm{A}^{2} / \mathrm{O}$ biofilm reactor performed well in removing chemical oxygen demand (COD), total nitrogen and total phosphorus. During three period, the influent concentrations of chemical oxygen demand, $\mathrm{NH}_{4}{ }^{+}-\mathrm{N}$, total phosphorus and total nitrogen $(\mathrm{mg} / \mathrm{L})$ were $954.04 \pm 19.45$, $143.74 \pm 7.66,23.51 \pm 1.52$ and $145.50 \pm 7.66$. The relevant removal efficiencies were $91.86 \pm 1.16,62.46 \pm 2.83,52.51 \pm 4.51$ and 54.73 $\pm 3.21 \%$, respectively; the accumulative rates of $\mathrm{NO}_{3}{ }^{-}-\mathrm{N}$ and $\mathrm{NO}_{2}{ }^{-}-\mathrm{N}$ were $413.72 \pm 76.50 \%$ and $1155.64 \pm 116.77 \%$. The novel biofilm carrier has some potential in the $\mathrm{A}^{2} / \mathrm{O}$ process for removing nutrients from sewage mixture.
\end{abstract}

Key Words: Activated carbon fiber felt, Biofilm reactor, Carrier, Fiber filler, Wastewater.

\section{INTRODUCTION}

The presence of nitrogenous and phosphorous substances in wastewater discharges contributes to eutrophication ${ }^{1,2}$. And thus biological nitrification-denitrification with phosphorous removal processes has attracted much concerns ${ }^{3,4}$. The anoxic/ aerobic $(\mathrm{A} / \mathrm{O})^{5}$, anaerobic/aerobic/anoxic $(\mathrm{AOA})^{6}$ and anaerobic/anoxic/aerobic $\left(\mathrm{A}^{2} / \mathrm{O}\right)^{7}$ activated sludge ${ }^{8}$ processes can efficiently remove organic matters, nitrogen and phosphorus. The shortcut nitrification-denitrification process has been researched in bioreactors ${ }^{9}$, wherein the $\mathrm{NH}_{4}{ }^{+}-\mathrm{N}$ was oxidized directly to $\mathrm{NO}_{2}^{-}-\mathrm{N}$, which possessed the advantages of saving in oxygen requirements for nitrification and carbon requirements for denitrification. The control of oxygen concentration was the main factor to achieve high removal rates of total nitrogen ${ }^{10}$.

A bioreactor with biofilm has proven to be reliable for nutrients removal in contrast to activated sludge process ${ }^{11-13}$. Many techniques with biofilm were applied, such as fixed media submerged biofilter, moving bed biofilm process and fluidized bed reactor. Recently, many researchers have focused on biofilm carriers, such as: sponge ${ }^{14}$, polyurethane foam cubes $^{15}$, tubular supports ${ }^{16}$, porous ceramic sticks with plastic rings ${ }^{17}$, polymer fiber ${ }^{18}$, flexible fiber ${ }^{19}$, etc. Meanwhile, activated carbon fiber cloth/felt ${ }^{20}$ have received attention as biofilm carrier in water treatment apparatus due to their inherent advantages that include: high specific surface area, minimal diffusion limitation to the adsorption and/or adherence of pollutants and bacteria, high mass transfer rate and high biomass loading. However, there are few papers which focused on $\mathrm{A}^{2} / \mathrm{O}$ biofilm process while fiber materials were applied as biofilm carrier for sewage disposal.

Therefore, the main objective of this study are: (1) determine the fundamental feasibility of a novel complex fiber filler (CFF) as biofilm carrier, which composed of an ultra-fine polypropylene fiber outer-coat and a polyacrylonitrile (PAN)based activated carbon fiber felt inner-core; (2) tentatively studied the $\mathrm{A}^{2} / \mathrm{O}$ biofilm reactor with complex fiber filler for sewage mixture treatment to remove organic carbon, nitrogen and phosphorus simultaneously.

\section{EXPERIMENTAL}

Characteristics of sewage mixture: The sewage mixture was collected from a wastewater collecting well in Beijing University of Chemical Technology (BUCT) where the sewage and septic tank effluent mixed together. During the experiments, the sewage mixture was pumped into a precipitation tank and then methanol, $\mathrm{Na}_{2} \mathrm{HPO}_{4}$ and $\left(\mathrm{NH}_{4}\right)_{2} \mathrm{SO}_{4}$ were added so as to adjust the influent chemical oxygen demand, $\mathrm{NH}_{4}{ }^{+}-\mathrm{N}$ and total phosphorus concentrations. The $\mathrm{pH}$ was adjusted by 
adding $\mathrm{NaOH}$ and/or $\mathrm{HCl}$ solutions. The suspended solids ( $\mathrm{SS}$ ) in the raw wastewater varied between $210-450 \mathrm{mg} / \mathrm{L}$. The total dissolved solids (TDS) ranged between 1253-1886 mg/L.

$\mathbf{A}^{2} / \mathrm{O}$ biofilm process: The $\mathrm{A}^{2} / \mathrm{O}$ biofilm reactor was composed of wastewater intake, purified water outlet, nitrification liquor reflux $\left(R_{1}\right)$ systems, sludge return $\left(R_{2}\right)$ systems, sludge discharge systems and aeration systems, as shown in Fig. 1(a). The $\mathrm{A}^{2} / \mathrm{O}$ process included five parts as followed: precipitation tank $\left(1.6 \times 1.2 \times 1.5 \mathrm{~m}\right.$, net volume $\left.2.5 \mathrm{~m}^{3}\right)$, anaerobic tank $(0.4 \times 0.6 \times 0.7 \mathrm{~m}$, net volume $120 \mathrm{~L})$, anoxic tank $(0.4 \times 0.6$ $\times 0.7 \mathrm{~m}$, net volume $120 \mathrm{~L})$, two oxic tanks $(0.5 \times 0.6 \times 0.7$ $\mathrm{m} \times 2$, net volume $300 \mathrm{~L})$ and settling tank $(\Phi 0.4 \times 0.55 \mathrm{~m}$, net volume $60 \mathrm{~L}$ ). The anaerobic and anoxic tanks were fixed with agitators and few carriers. The oxic tanks were fixed with a great many carriers and air distributing pipe with micropore. An automatic water temperature controller and a heater were used to adjust the influent wastewater temperature between $27-33^{\circ} \mathrm{C}$. Five peristaltic pumps with digital display were used to promote liquor flow in the plastic hose. Excess sludge was discharged by the hand-operated valve under the bottom of each tank.

Complex fiber filler biofilm carrier: In Fig. 1(b), the complex fiber filler in the $\mathrm{A}^{2} / \mathrm{O}$ biofilm reactor was composed of an outer-coat $(\Phi 0.04 \times 0.5 \mathrm{~m})$ and an inner-core $(\Phi 0.02 \times$ $0.45 \mathrm{~m})$. The outer-coat comprised in fibrous reticular cloth on which many poly-propylene ultra-fine fiber loops $(0.04 \mathrm{~m}$ length) were planted, provided by Hebei Yisheng Environment Protection Technique Co., Ltd. The inner-core was PAN-based activated carbon fiber felt (PAN-ACFF, thick $2 \mathrm{~mm}$, specific surface area $1200 \mathrm{~m}^{2} / \mathrm{g}$ ), provided by the National Carbon Fiber Engineering Research Center in BUCT. The complex fiber filler shared the characteristics of high specific surface area $\left(1450 \pm 100 \mathrm{~m}^{2} / \mathrm{g}\right)$, high porosity (> $\left.95 \%\right)$, low hydraulic resistance, be easy for microorganisms to adhere and accessible for biofilm to scour off.

While used as biofilm carrier in the $\mathrm{A}^{2} / \mathrm{O}$ process, four bunches (each bunch $35 \mathrm{~g}$ ) of the complex fiber filler were fixed on a stainless steel framework (as a fixed bed). As a whole, there were 64 bunches was used in the oxic tanks and 32 bunches in the anoxic/anaerobic tanks. The wet volume of the 96 bunches of complex fiber filler was around $0.09 \mathrm{~m}^{3}$. Finally, the net volume of the $\mathrm{A}^{2} / \mathrm{O}$ process was about $0.5 \mathrm{~m}^{3}$.

Analytical methods and equipments: Samples for test were collected between 07:00-09:00 from the supernatants of the precipitation tank and the settling tank, respectively. All the samples were centrifugated (Kokusan H-9R, Japan) at $12,000 \mathrm{rad} / \mathrm{min}$ for $3 \mathrm{~min}$ at $5{ }^{\circ} \mathrm{C}$ before test. The tests of chemical oxygen demand, $\mathrm{NH}_{4}{ }^{+}-\mathrm{N}, \mathrm{NO}_{3}{ }^{-}-\mathrm{N}, \mathrm{NO}_{2}{ }^{-}-\mathrm{N}$, total phosphorus, TSS, $\mathrm{pH}, \mathrm{DO} / \mathrm{Temperature}$ and TDS were carried out by referring to the 4th edition of Monitoring and Analyzing Methods of Water and Wastewater (Environmental Protection Agency of P.R. China).

Experimental design: Filling with the complex fiber filler, the $\mathrm{A}^{2} / \mathrm{O}$ biofilm reactor was used for sewage mixture treatment in this study. The seed sludge was obtained from Qing He urban W.W.T.P. in Beijing. The biofilm reactor was seeded at April 1st. The influent flow $\left(\mathrm{F}_{1}\right)$ increased gradually to $1 \mathrm{~m}^{3} / \mathrm{d}$ and the ratio of $\mathrm{R}_{1} / \mathrm{F}_{1}$ equaled to $1 / 1$. The $\mathrm{pH}$ of the
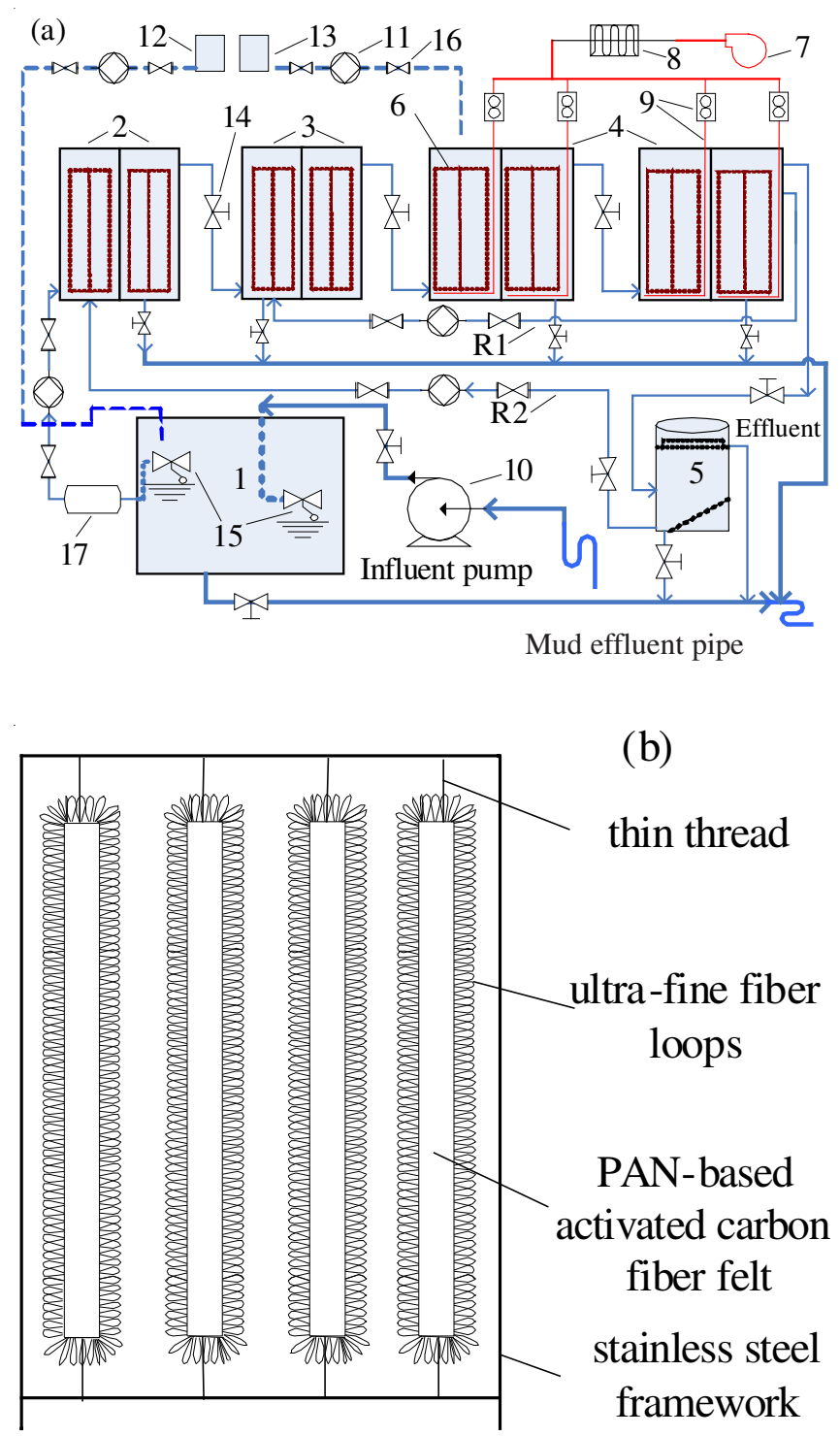

Fig. 1. Schematic diagram of the $\mathrm{A}^{2} / \mathrm{O}$ biofilm reactor (a) and the complex fiber filler (CFF) fixed bed (b); 1, precipitation tank; 2, anaerobic tank; 3, anoxic tank; 4, oxic tank; 5, settling tank; 6, CFF fixed bed; 7, blower; 8, air compressor; 9, air flow meter and air distributing pipe with micropore; 10, high-lift pump; 11, digital display peristaltic pump; 12 , alkali tank; 13 , acid tank; 14 , handoperated valve; 15 , floating ball liquid level controller; 16, flange; 17 , automatic water temperature controller and heater

raw wastewater was kept between 6.5-7.9. Dissolved oxygen (DO) was maintained to lower than $0.2 \mathrm{mg} / \mathrm{L}$ in the anaerobic tanks, lower than $0.5 \mathrm{mg} / \mathrm{L}$ in the an oxic tanks and between 2.0-3.0 $\mathrm{mg} / \mathrm{L}$ in the oxic tanks. The MLSS (mixed liquor suspended solids) in all the tanks was $2.0 \pm 0.3 \mathrm{~g} / \mathrm{L}$. While the chemical oxygen demand removal percentages were steadily kept above $60 \%$ and all the fibers were covered by biofilm, the samples were continuously collected and tested every other day for one month as Period 1; then increased the $R_{1}$ and continued to experiment as Period 2/Period 3. Parameters were as followed:

Period 1: $F_{1}$ was $1.0 \mathrm{~m}^{3} / \mathrm{d}, R_{1}$ was $2.0 \mathrm{~m}^{3} / \mathrm{d}$ and $R_{2}$ was $0.4 \mathrm{~m}^{3} / \mathrm{d}$. Period 2: $F_{1}$ was $1.0 \mathrm{~m}^{3} / \mathrm{d}, R_{1}$ was $3.0 \mathrm{~m}^{3} / \mathrm{d}$ and $R_{2}$ was $0.4 \mathrm{~m}^{3} / \mathrm{d}$. Period 3: $F_{1}$ was $1.0 \mathrm{~m}^{3} / \mathrm{d}, R_{1}$ was $4.0 \mathrm{~m}^{3} / \mathrm{d}$ and $R_{2}$ was $0.4 \mathrm{~m}^{3} / \mathrm{d}$. 
wherein, the total hydraulic retention time (HRT) was $12 \mathrm{~h}$; the sludge residence time (SRT) for the anaerobic-anoxic tanks were $7 \mathrm{~d}$ and for the oxic tanks were $10 \mathrm{~d}$.

\section{RESULTS AND DISCUSSION}

Observation of biofilm on complex fiber filler: Pictures of the complex fiber filler were taken by digital camera and scanning electron microscope (SEM, HITACHI SUI510) before and after biofilm formed. The microorganisms grew on the outer surfaces and the interior surfaces of the novel fibrous carriers and formed biofilm. As shown in Fig. 2(a,b), the biofilm on the surface of the fibrous materials could be observed obviously. Meanwhile, the activated sludge grew in the suspended spaces of the $\mathrm{A}^{2} / \mathrm{O}$ bioreactor.

It was found that the biofilm formed rapidly and was shear sensitive to the up flow air-water mixture. While collected from the wastewater bioreactor, the ultra-fine organic fiber loops remained little biofilms (Fig. 2c,d); So the biofilm on the fiber loops could regenerate in situ, which was essential for the stable performance of the biofilm reactor in long term. However, it was difficult to remove the biofilm on the PAN-ACFF innercore (Fig. 2e,f). The sludge residence time of all the tanks was set shorter than that in the conventional $\mathrm{A}^{2} / \mathrm{O}$ process in order to discharge excess sludge to avoid blocking the media. The transfer of oxygen and nutrients across the biofilm would be available for the existence of large amount of ventilation holes and channels among filaments (Fig. 2d,f). Furthermore, the anaerobic-anoxic-oxic microenvironments were rich and the microorganisms could construct a complex microecosystem in the biofilm reactor with complex fiber filler.
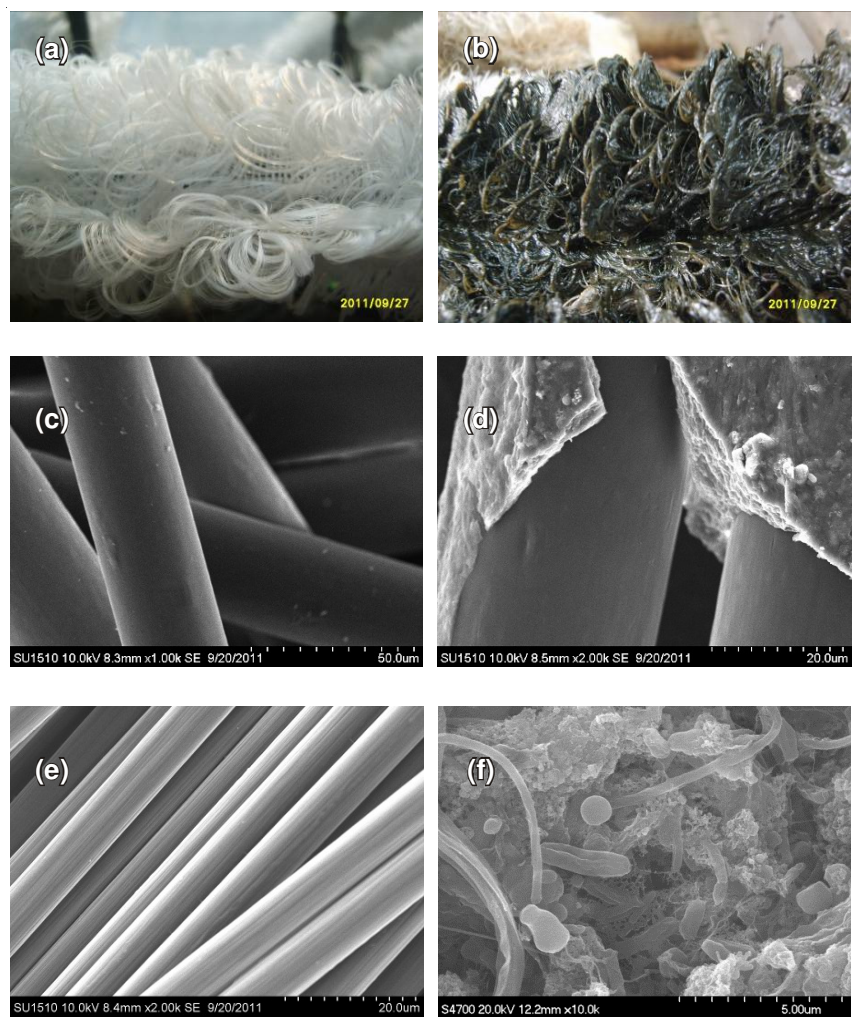

Fig. 2. Pictures of complex fiber filler (CFF) (a, b), SEM of ultra-fine organic fiber loops (c, d) and activated carbon fiber felt (e, f).
Removal of chemical oxygen demand, $\mathrm{NH}_{4}{ }^{+}-\mathrm{N}$ and total phosphorus: During Period 1, Period 2 and Period 3, the removal percentages of chemical oxygen demand, $\mathrm{NH}_{4}{ }^{+}-\mathrm{N}$ and total phosphorus varied along with $\mathrm{R}_{1}$ increased, as shown in Fig. 3(a,b,c).

From Fig. 3(a,c), it can be seen clearly that the influent chemical oxygen demand and total phosphorus concentrations fluctuated slightly during different Periods; in contrast, the influent $\mathrm{NH}_{4}{ }^{+}-\mathrm{N}$ concentrations descended notably. Meanwhile, the effluent chemical oxygen demand concentrations were low and stable (Fig. 3b); and the effluent $\mathrm{NH}_{4}{ }^{+}-\mathrm{N}$ and total phosphorus concentrations were high but declined gradually. Thus, during Period 1, Period 2 and Period 3, the removal percentages for chemical oxygen demand were $89.45 \pm 1.18,90.11 \pm 0.87$ and $91.86 \pm 1.16 \%$; for $\mathrm{NH}_{4}{ }^{+}-\mathrm{N}$ were $43.96 \pm 3.86,50.90 \pm$ 3.09 and $62.46 \pm 2.83 \%$; for total phosphorus were $38.30 \pm$ $3.09,47.44 \pm 2.59$ and $52.51 \pm 4.51 \%$. The relevant data were detailed shown in Table-1.
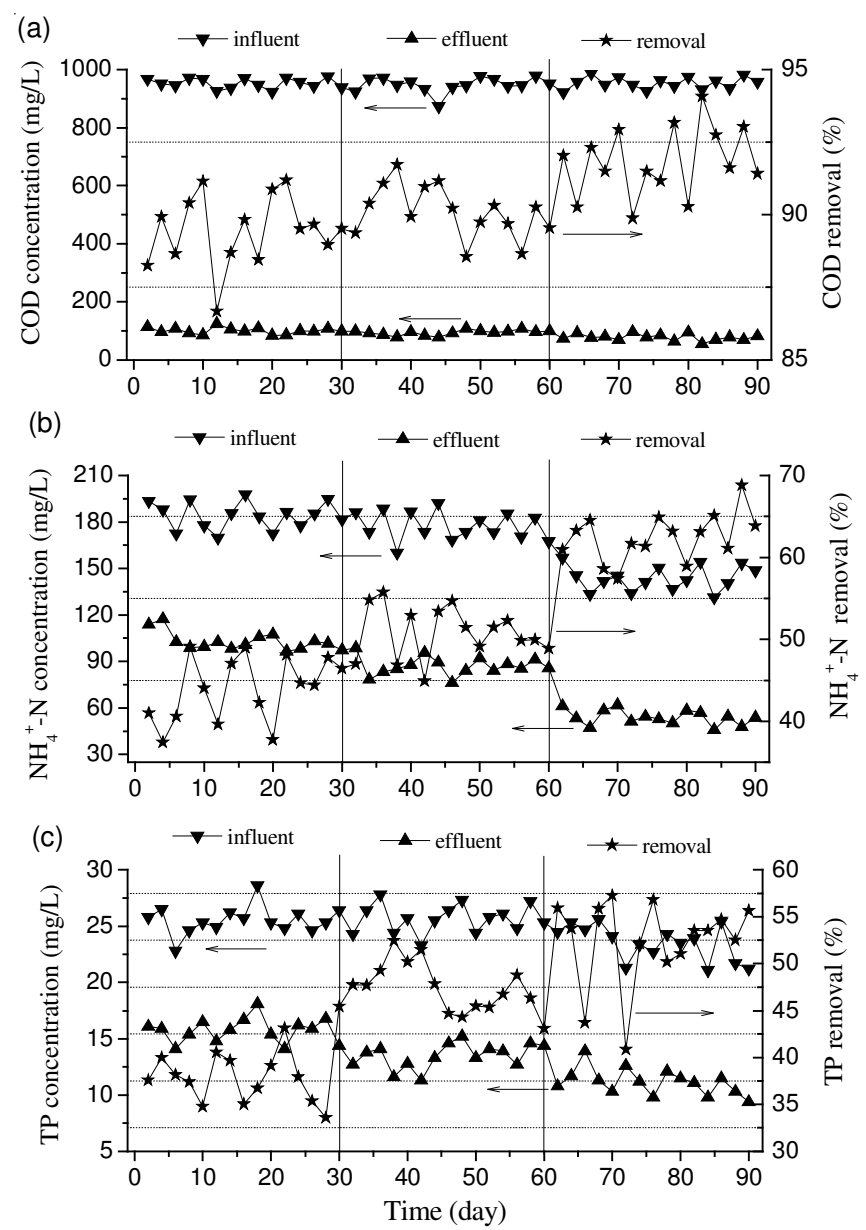

Fig. 3. The concentrations of chemical oxygen demand (COD), $\mathrm{NH}_{4}{ }^{+}-\mathrm{N}$, total phosphorus in the bioreactor

During the tests for three Periods, the raw wastewater was artificially adjusted and thus the ratios of chemical oxygen demand/ $\mathrm{NH}_{4}{ }^{+}-\mathrm{N}$ were 5.18, 5.34 and 6.64; the ratios of chemical oxygen demand/total phosphorus were $37.32,38.47$ and 40.58 . Meanwhile, the $R_{1}$ increased from $2.0 \mathrm{~m}^{3} / \mathrm{d}, 3.0 \mathrm{~m}^{3} / \mathrm{d}$ to 4.0 $\mathrm{m}^{3} / \mathrm{d}$. Accordingly, the $\mathrm{R}_{1} / \mathrm{F}_{1}$ were $2 / 1,3 / 1$ and $4 / 1$; which may be the main factor that promote the rose of the removal rates 
TABLE-1

REMOVAL OF COD, $\mathrm{NH}_{4}{ }^{+}-\mathrm{N}$ AND TOTAL PHOSPHORUS (STANDARD DEVIATION)

\begin{tabular}{|c|c|c|c|c|c|c|c|c|c|}
\hline & \multicolumn{3}{|c|}{ COD } & \multicolumn{3}{|c|}{$\mathrm{NH}_{4}^{+}-\mathrm{N}$} & \multicolumn{3}{|c|}{ Total phosphorus } \\
\hline & $\begin{array}{l}\text { Influent } \\
\text { (g/d) }\end{array}$ & $\begin{array}{l}\text { Effluent } \\
\text { (g/d) }\end{array}$ & $\begin{array}{c}\text { Removal } \\
(\%)\end{array}$ & $\begin{array}{l}\text { Influent } \\
(\mathrm{g} / \mathrm{d})\end{array}$ & $\begin{array}{l}\text { Effluent } \\
\text { (g/d) }\end{array}$ & $\begin{array}{c}\text { Removal } \\
(\%)\end{array}$ & $\begin{array}{l}\text { Influent } \\
(\mathrm{g} / \mathrm{d})\end{array}$ & $\begin{array}{l}\text { Effluent } \\
(\mathrm{g} / \mathrm{d})\end{array}$ & $\begin{array}{c}\text { Removal } \\
(\%)\end{array}$ \\
\hline Period 1 & $\begin{array}{l}952.89 \\
(16.84)\end{array}$ & $\begin{array}{c}100.45 \\
(10.68)\end{array}$ & $\begin{array}{l}89.45 \\
(1.18)\end{array}$ & $\begin{array}{c}184.08 \\
(8.49)\end{array}$ & $\begin{array}{c}102.97 \\
(5.85)\end{array}$ & $\begin{array}{l}43.96 \\
(3.86)\end{array}$ & $\begin{array}{l}25.53 \\
(1.22)\end{array}$ & $\begin{array}{l}15.75 \\
(1.06)\end{array}$ & $\begin{array}{l}38.30 \\
(3.09)\end{array}$ \\
\hline Period 2 & $\begin{array}{l}948.40 \\
(25.44) \\
\end{array}$ & $\begin{array}{l}93.82 \\
(8.81) \\
\end{array}$ & $\begin{array}{l}90.11 \\
(0.87) \\
\end{array}$ & $\begin{array}{c}177.51 \\
(8.90) \\
\end{array}$ & $\begin{array}{l}87.07 \\
(5.70) \\
\end{array}$ & $\begin{array}{l}50.90 \\
(3.09) \\
\end{array}$ & $\begin{array}{l}24.65 \\
(1.21) \\
\end{array}$ & $\begin{array}{l}13.49 \\
(1.08) \\
\end{array}$ & $\begin{array}{l}47.44 \\
(2.59) \\
\end{array}$ \\
\hline Period 3 & $\begin{array}{l}954.04 \\
(19.45)\end{array}$ & $\begin{array}{c}77.65 \\
(11.19)\end{array}$ & $\begin{array}{l}91.86 \\
(1.16)\end{array}$ & $\begin{array}{c}143.74 \\
(7.66)\end{array}$ & $\begin{array}{l}53.93 \\
(4.74) \\
\end{array}$ & $\begin{array}{l}62.46 \\
(2.83)\end{array}$ & $\begin{array}{l}23.51 \\
(1.52)\end{array}$ & $\begin{array}{l}11.15 \\
(1.14)\end{array}$ & $\begin{array}{l}52.51 \\
(4.51)\end{array}$ \\
\hline
\end{tabular}

TABLE-2

CONCENTRATIONS OF $\mathrm{NO}_{3}^{-}-\mathrm{N}, \mathrm{NO}_{2}^{-}-\mathrm{N}$ AND TOTAL NITROGEN (STANDARD DEVIATION)

\begin{tabular}{|c|c|c|c|c|c|c|c|c|c|}
\hline & \multicolumn{3}{|c|}{$\mathrm{NO}_{3}^{-}-\mathrm{N}$} & \multicolumn{3}{|c|}{$\mathrm{NO}_{2}^{-}-\mathrm{N}$} & \multicolumn{3}{|c|}{ Total nitrogen } \\
\hline & $\begin{array}{l}\text { Influent } \\
(\mathrm{g} / \mathrm{d})\end{array}$ & $\begin{array}{l}\text { Effluent } \\
(\mathrm{g} / \mathrm{d})\end{array}$ & $\begin{array}{c}\text { Accumulation } \\
(\%)\end{array}$ & $\begin{array}{l}\text { Influent } \\
(\mathrm{g} / \mathrm{d})\end{array}$ & $\begin{array}{c}\text { Effluent } \\
(\mathrm{g} / \mathrm{d})\end{array}$ & $\begin{array}{c}\text { Accumulation } \\
(\%)\end{array}$ & $\begin{array}{l}\text { Influent } \\
(\mathrm{g} / \mathrm{d})\end{array}$ & $\begin{array}{l}\text { Effluent } \\
(\mathrm{g} / \mathrm{d})\end{array}$ & $\begin{array}{c}\text { Removal } \\
(\%)\end{array}$ \\
\hline Period 1 & $\begin{array}{c}1.47 \\
(0.18) \\
\end{array}$ & $\begin{array}{l}19.02 \\
(2.30) \\
\end{array}$ & $\begin{array}{c}1199.78 \\
(125.10) \\
\end{array}$ & $\begin{array}{c}0.65 \\
(0.12) \\
\end{array}$ & $\begin{array}{l}14.60 \\
(2.70) \\
\end{array}$ & $\begin{array}{l}2143.47 \\
(137.75) \\
\end{array}$ & $\begin{array}{l}186.20 \\
(8.49) \\
\end{array}$ & $\begin{array}{c}136.60 \\
(6.35) \\
\end{array}$ & $\begin{array}{l}26.54 \\
(3.71) \\
\end{array}$ \\
\hline Period 2 & $\begin{array}{c}1.58 \\
(0.37) \\
\end{array}$ & $\begin{array}{l}14.11 \\
(2.89) \\
\end{array}$ & $\begin{array}{c}802.46 \\
(110.26) \\
\end{array}$ & $\begin{array}{c}0.64 \\
(0.12) \\
\end{array}$ & $\begin{array}{l}11.80 \\
(2.14) \\
\end{array}$ & $\begin{array}{r}1746.90 \\
(132.55)\end{array}$ & $\begin{array}{l}179.74 \\
(8.82) \\
\end{array}$ & $\begin{array}{l}112.97 \\
(5.89) \\
\end{array}$ & $\begin{array}{l}37.03 \\
(3.85) \\
\end{array}$ \\
\hline Period 3 & $\begin{array}{c}1.37 \\
(0.20) \\
\end{array}$ & $\begin{array}{c}6.92 \\
(0.86) \\
\end{array}$ & $\begin{array}{l}413.72 \\
(76.50) \\
\end{array}$ & $\begin{array}{c}0.40 \\
(0.07) \\
\end{array}$ & $\begin{array}{c}4.97 \\
(0.88) \\
\end{array}$ & $\begin{array}{c}1155.64 \\
(116.77) \\
\end{array}$ & $\begin{array}{l}145.50 \\
(7.66) \\
\end{array}$ & $\begin{array}{l}65.82 \\
(5.18) \\
\end{array}$ & $\begin{array}{l}54.73 \\
(3.21) \\
\end{array}$ \\
\hline
\end{tabular}

of chemical oxygen demand, $\mathrm{NH}_{4}{ }^{+}-\mathrm{N}$ and total phosphorus. High removal rates of chemical oxygen demand achieved for large amount of microorganisms grew on the biofilm and in the suspended activated sludge. The $\mathrm{NH}_{4}{ }^{+} \mathrm{N}$ was removed at low level because the $\mathrm{O}_{2}$ concentration was not enough for nitrification. However, total phosphorus removed by the removal of sludge from all the tanks.

Removal of nitrogen: The concentrations of $\mathrm{NO}_{3}^{-}-\mathrm{N}$ and $\mathrm{NO}_{2}^{-}-\mathrm{N}$ in the influent and effluent were tested in order to observe the nitrification-denitrification situation in the biofilm process with complex fiber filler [Fig. 4(a,b)].
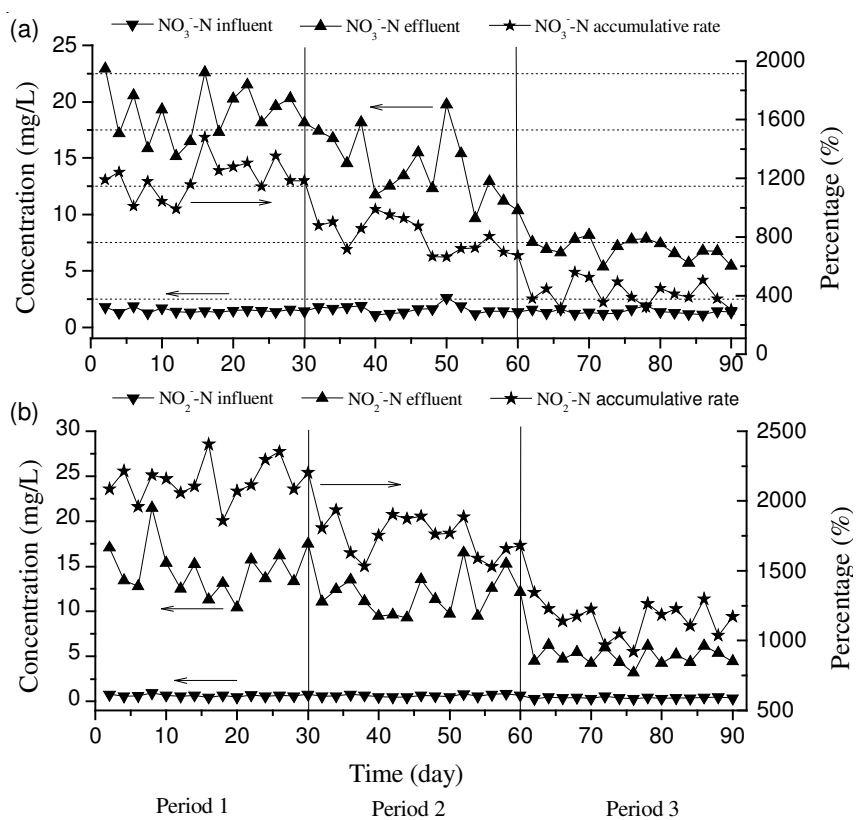

Fig. 4. Concentrations of $\mathrm{NO}_{3}^{-}-\mathrm{N}$ and $\mathrm{NO}_{2}^{-}{ }^{-} \mathrm{N}$ in the bioreactor

It can be seen that the influent $\mathrm{NO}_{3}^{-}-\mathrm{N}$ and $\mathrm{NO}_{2}^{-}-\mathrm{N}$ concentrations were very low and steady. In contrast, the relevant effluent concentrations were high and descended dramatically during the three Periods. Wherein, the accumulative rates of $\mathrm{NO}_{3}^{-}-\mathrm{N}$ and $\mathrm{NO}_{2}^{-}-\mathrm{N}$ were calculated by an equation of (effluent - influent)/effluent $\times 100 \%$. Furthermore, the accumulative rates for $\mathrm{NO}_{3}{ }^{-}-\mathrm{N}$ were $1199.78 \pm 125.10,802.46$ \pm 110.26 and $413.72 \pm 76.50 \%$; for $\mathrm{NO}_{2}^{-}-\mathrm{N}$ were $2143.47 \pm$ $137.75,1746.90 \pm 132.55$ and $1155.64 \pm 116.77 \%$, respectively. The accumulative rates of $\mathrm{NO}_{3}^{-}-\mathrm{N}$ and $\mathrm{NO}_{2}^{-}-\mathrm{N}$ were very high because the oxygen concentrations were controlled at low level. Furthermore, the accumulation of $\mathrm{NO}_{2}{ }^{-} \mathrm{N}$ in large amount provided the possibility of shortcut nitrificationdenitrification.

Moreover, the total nitrogen $(\mathrm{TN})$ removal percentages were calculated by an equation $\left(\mathrm{TN}=\mathrm{NH}_{4}{ }^{-}-\mathrm{N}+\mathrm{NO}_{3}{ }^{-} \mathrm{N}+\right.$ $\mathrm{NO}_{2}^{-}-\mathrm{N}$ ). As shown in Table-2, the removal percentages of total nitrogen during Period 1, Period 2 and Period 3 were $26.54 \pm 3.71,37.03 \pm 3.85$ and $54.73 \pm 3.21 \%$.

In general, the optimum removal efficiencies achieved during Period 3, where the influent concentrations of chemical oxygen demand, $\mathrm{NH}_{4}{ }^{+}-\mathrm{N}$, total phosphorus and total nitrogen were $954.04 \pm 19.45 \mathrm{mg} / \mathrm{L}, 143.74 \pm 7.66 \mathrm{mg} / \mathrm{L}, 23.51 \pm 1.52$ $\mathrm{mg} / \mathrm{L}$ and $145.50 \pm 7.66 \mathrm{mg} / \mathrm{L}$; the average loading rates were $1908.08 \mathrm{~g} \mathrm{COD} /\left(\mathrm{m}^{3} \mathrm{~d}\right), 287.48 \mathrm{gNH}_{4}{ }^{+} \mathrm{N} /\left(\mathrm{m}^{3} \mathrm{~d}\right), 47.02 \mathrm{~g}$ total phosphorus $/\left(\mathrm{m}^{3} \mathrm{~d}\right)$ and $291 \mathrm{~g}$ total nitrogen $/\left(\mathrm{m}^{3} \mathrm{~d}\right)$; accordingly, the removal efficiencies were $91.86 \pm 1.16,62.46 \pm 2.83,52.51$ \pm 4.51 and $54.73 \pm 3.21 \%$, respectively; the accumulative rates of $\mathrm{NO}_{3}{ }^{-}-\mathrm{N}$ and $\mathrm{NO}_{2}{ }^{-}-\mathrm{N}$ were $413.72 \pm 76.50$ and $1155.64 \pm$ $116.77 \%$.

\section{Conclusion}

This paper investigated a novel complex fibrous biofilm carrier which was composed of an outer-coat and an innercore. And then the novel complex fiber filler carrier was applied in an $\mathrm{A}^{2} / \mathrm{O}$ process for sewage mixture treatment. Results showed that the biofilm on the complex fiber filler outer surface formed fast and was shear sensitive; the optimum average removal efficiencies of chemical oxygen demand, $\mathrm{NH}_{4}{ }^{+} \mathrm{N}$, total phosphorus and total nitrogen achieved during Period 3; 
Moreover, the accumulative rates of $\mathrm{NO}_{3}{ }^{-}-\mathrm{N}$ and $\mathrm{NO}_{2}{ }^{-}-\mathrm{N}$ were quite high during the tests because of the low concentration of $\mathrm{O}_{2}$. Therefore, the novel biofilm carrier has potential to be applied in biofilm process for wastewater treatment.

\section{ACKNOWLEDGEMENTS}

The authors thank the Major Science and Technology Program for Water Pollution Control and Treatment (2009ZX07526-005-05) for financial support.

\section{REFERENCES}

1. S.B. Grant, J.D. Saphores, D.L. Feldman, A.J. Hamilton, T.D. Fletcher, P.L.M. Cook, M. Stewardson, B.F. Sanders, L.A. Levin, R.F. Ambrose, A. Deletic, R. Brown, S.C. Jiang, D. Rosso, W.J. Cooper and I. Marusic, Science, 337, 681 (2012)

2. Z. Wang, Science, 338, 604 (2012).

3. M. Sibag and H.-S. Kim, Bioresour. Technol., 104, 173 (2012).

4. A. Gonzalez-Martinez, J.M. Poyatos, E. Hontoria, J. Gonzalez-Lopez and F. Osorio, Recent Pat. Biotechnol., 5, 74 (2011).

5. A.R. Sani, N. Mehrdadi and A. Azimi, Asian J. Chem., 25, 1177 (2013).

6. X.Y. Xu, G. Liu and L. Zhu, Bioresour. Technol., 102, 10340 (2011).
7. X. Wang, J.X. Liu, N.-Q. Ren and Z.S. Duan, Bioresour. Technol., 126, 31 (2012).

8. X.J. Du, X.H. Hao, H.J. Li and Y.W. Ma, Asian J. Chem., 23, 4457 (2011).

9. S. Yang and F.L. Yang, J. Hazard. Mater, 195, 318 (2011).

10. W. Kwak, P.L. McCarty, J.H. Bae, Y.-T. Huang and P.-H. Lee, Bioresour. Technol., 123, 400 (2012).

11. V. Singh and A.K. Mittal, Water Sci. Technol., 66, 429 (2012).

12. L.C. Koh, H. Zhang, T.T. Nguyen and S.L. Ong, Water Sci. Technol., 65, 484 (2012).

13. H. Liu, F. Yang, S. Shi and X. Liu, J. Environ. Sci. (China), 22, 540 (2010).

14. L. Zhang, K. Sun and N. Hu, Water Sci. Technol., 65, 190 (2012).

15. J.-W. Lim, C.-E. Seng, P.-E. Lim, S.-L. Ng and A.-N.A. Sujari, Bioresour. Technol., 102, 9876 (2011).

16. A. Luciano, P. Viotti, G. Mancini and V. Torretta, J. Environ. Manage., 113, 51 (2012).

17. Y.H. Lin, Water Sci. Technol., 62, 985 (2010).

18. L. Jurecska, K. Barkács, É. Kiss, G. Gyulai, T. Felföldi, B. Töro, R. Kovács and G. Záray, Microchem. J., 107, 108 (2013).

19. Y. Chen, J. Yu, H.W. Xu and Y. Chen, Chin. J. Chem. Eng., 17, 879 (2009).

20. Y. Chen, M. Liu, F. Xu, S. Zhu and S. Shen, Water Sci. Technol., 62, 1052 (2010). 